\title{
Gambaran histopatologik ginjal tikus wistar (Rattus norvegicus) yang diinduksi gentamisin dan diberikan ubi jalar ungu (Ipomoea batatas L. Poir)
}

\author{
${ }^{1}$ Grace S. Siahaan \\ ${ }^{2}$ Poppy M. Lintong \\ ${ }^{2}$ Lily L. Loho
}

\author{
${ }^{1}$ Kandidat Skripsi Fakultas Kedokteran Universitas Sam Ratulangi Manado \\ ${ }^{2}$ Bagian Patologi Anatomi Fakultas Kedokteran Universitas Sam Ratulangi Manado \\ Email: shandysiahaan12284@gmail.com
}

\begin{abstract}
Gentamycin is known as one of the nephrotoxic agents. Purple sweet potato (Ipomoea batatas L. Poir) is rich of antioxidant due to its high anthocyanin content. This study aimed to obtain the histopathological features of the kidney of Wistar rats induced by gentamycin and were given purple sweet potato. This was an experimental laboratory study. Subjects were 24 Wistar rats. Group I (negative control) consisted of 4 rats, fed with pellets $\left(\mathrm{AD}_{2}\right)$ for 7 days. Group IIA and IIB consisted of 4 rats each, induced by gentamicin for 7 and 10 days each. Group IIIA and IIIB consisted of 4 rats each, induced by gentamicin for 7 and 10 days and then were given purple sweetpotato extract for 7 days. Group IV consisted of 4 rats induced by gentamicin for 7 days then were fed with pellets $\left(\mathrm{AD}_{2}\right)$ for 7 days. The results showed hydropic degeneration, necrosis, and fibrosis of kidney tubule epithelial cells in group IIA and B. Group III A and B showed regeneration of kidney tubule epithelial cells, while hydropic degeneration and necrosis focus reduced more than group II A and B. Group IV showed epithelial cell regeneration, yet still showed hydropic degeneration and necrosis. Conclusion: Supplementation of purple sweet potato extract to Wistar rats induced with gentamycin showed more regeneration of kidney tubule epithelial cells compared to the Wistar rats without supplementation of purple sweet potato extract.

Keywords: kidney, gentamicin, purple sweet potato extract
\end{abstract}

\begin{abstract}
Abstrak: Gentamisin merupakan salah satu agen nefrotoksik. Ubijalar ungu (Ipomoea batatas L. Poir) sebagai tanaman kaya antioksidan memiliki senyawa antosianin tinggi. Penelitian ini bertujuan untuk mengetahui gambaran histopatologik ginjal tikus wistar yang diinduksi gentamisin dan diberikan ubi jalar ungu (Ipomoea batatas L. Poir). Jenis penelitian ini eksperimental laboratorik dengan menggunakan 24 ekor tikus wistar sebagai hewan coba. Kelompok I (kontrol negatif) sebanyak 4 ekor hanya diberi makan pelet $\mathrm{AD}_{2}$ selama 7 hari. Kelompok IIA dan IIB masing-masing sebanyak 4 ekor, diinduksi gentamisin selama 7 dan 10 hari. Kelompok IIIA dan IIIB masing-masing sebanyak 4 ekor, diinduksi gentamisin selama 7 dan 10 hari kemudian diberikan ekstrak ubijalar ungu selama 7 hari. Kelompok IV sebanyak 4 ekor diinduksi gentamisin selama 7 hari dan diberikan pelet $\mathrm{AD}_{2}$ selama 7 hari. Hasil penelitian menunjukkan degenerasi hidropik, nekrosis dan fibrosis pada sel epitel tubulus ginjal tikus yang diberi gentamisin. Pemberian ekstrak ubi jalar ungu pada tikus yang diinduksi gentamisin menunjukkan regenerasi sel epitel tubulus ginjal, sedangkan fokus degenerasi hidropik dan nekrosis semakin berkurang. Kelompok tanpa pemberian ekstrak ubi jalar ungu menunjukkan regenerasi sel epitel namun gambaran degenerasi hidropik dan nekrosis masih tampak. Simpulan: Pemberian ekstrak ubi jalar ungu pada tikus wistar paska induksi gentamisin menunjukkan regenerasi sel epitel tubulus lebih luas dibandingkan yang tanpa pemberian ekstrak ubijalar ungu.
\end{abstract}

Kata kunci: ginjal, gentamisin, ekstrak ubijalar ungu 
Gentamisin tergolong antibiotika aminoglikosida yang sudah diketahui toksik terhadap ginjal. Akibat yang dapat ditimbulkan oleh agen nefrotoksik ini salah satunya adalah kerusakan tubulus ginjal. ${ }^{1-3}$ Penelitian oleh Sondakh (2012) membuktikan bahwa pemberian gentamisin dosis toksik 0,3 $\mathrm{ml} /$ hari selama tujuh dan sepuluh hari menyebabkan terjadinya degenerasi hidropik yang luas, perlemakan, dan nekrosis pada tubulus ginjal tikus Wistar.

Pembentukan radikal bebas oleh bahan nefrotoksik diduga ikut berperan dalam menyebabkan cedera sel. ${ }^{5}$ Respons tubuh untuk menangkal radikal bebas ialah dengan memroduksi antioksidan endogen. Namun, jika radikal bebas yang terbentuk melampaui jumlah antioksidan endogen, maka dibutuhkan antioksidan eksogen untuk mengimbanginya. Penelitian terhadap peran antioksidan eksogen pada ginjal yang diinduksi agen toksik dilakukan oleh Elango (2015) ${ }^{6}$ dengan menggunakan tanaman obat Siddha dari India yakni Ipomoea obscura L. dan didapatkan hasil adanya pengurangan signifikan jumlah lesi yang terbentuk. ${ }^{6}$

Antioksidan eksogen alami dapat diperoleh dari berbagai jenis tanaman. Salah satu tanaman yang memiliki kandungan antioksidan tinggi yaitu ubijalar ungu (Ipomoea batatas L. Poir). ${ }^{7,8}$ Kandungan antioksidan, khususnya antosianin yang dimiliki oleh ubi jalar ungu berkorelasi dengan warna predominan daging umbi ubi jalar ungu. Semakin pekat warna ungu dari ubi jalar ungu, semakin tinggi kandungan antosianin umbi. ${ }^{8}$ Penelitian yang dilakukan oleh Pandir dan Kara $^{9}$ menggunakan tanaman dengan kandungan antosianin tinggi yaitu bilberry (Vaccinum myrtillus L.) pada kelinci yang diinduksi sisplatin menunjukkan adanya pengurangan bermakna jaringan ginjal yang rusak.

Penelitian ini bertujuan untuk mengetahui gambaran histopatologik ginjal tikus wistar yang diinduksi gentamisin dan diberikan ubi jalar ungu (Ipomoea batatas L. Poir).

\section{METODE PENELITIAN}

Penelitian ini dilakukan sejak bulan September 2015 sampai bulan Februari 2016 di Laboratorium Patologi Anatomi Fakultas Kedokteran Universitas Sam Ratulangi dengan menggunakan desain penelitian eksperimental.

Subjek penelitian yang digunakan sebanyak 24 ekor tikus Wistar, terdiri dari kelompok kontrol 4 ekor dan kelompok perlakuan 20 ekor yang dibagi menjadi 5 kelompok. Tikus Wistar diberi makan pelet $\mathrm{AD}_{2}$ dan masing-masing tikus dimasukkan dalam kandang sesuai kelompok. Penentuan dosis toksik ditentukan berdasarkan dosis toksik pada manusia yaitu 10 kali dosis terapi (6 mg). Dengan demikian dosis yang digunakan untuk tikus dengan berat badan rata-rata $200 \mathrm{mg}$ ialah 0,3 ml. Ekstrak ubi jalar ungu yang digunakan yaitu ekstrak yang dibuat di Laboratorium Farmasi Fakultas MIPA Universitas Sam Ratulangi Manado dengan menggunakan metode pelarut etanol 96\% sebanyak tiga kali ektraksi dengan perbandingan bubuk ubi jalar ungu dan pelarut ialah 1:5. Dosis yang digunakan ialah $200 \mathrm{mg} / \mathrm{ekor}$.

Kelompok I (kontrol negatif) hanya diberi makan pelet $\mathrm{AD}_{2}$ selama 7 hari kemudian diterminasi pada hari ke-8. Kelompok IIA diinduksi gentamisin dosis toksik $(0,3 \mathrm{ml})$ selama 7 hari kemudian diterminasi pada hari ke-8. Kelompok IIB diinduksi gentamisin dosis toksik $(0,3 \mathrm{ml})$ selama 10 hari kemudian diterminasi pada hari ke-11. Kelompok IIIA diinduksi gentamisin dosis toksik $(0,3 \mathrm{ml})$ selama 7 hari kemudian diberikan ekstrak ubi jalar ungu dosis terapi (200 mg/ekor) selama 7 hari, setelah itu diterminasi pada hari ke15. Kelompok IIIB diinduksi gentamisin dosis toksik $(0,3 \mathrm{ml})$ selama 10 hari kemudian diberikan ekstrak ubi jalar ungu dosis terapi (200 mg/ekor) selama 7 hari, setelah itu diterminasi pada hari ke-18. Kelompok IV diinduksi gentamisin dosis toksik (0,3 ml) selama 7 hari dan diberikan pelet $\mathrm{AD}_{2}$ selama 7 hari kemudian diterminasi pada hari ke-15.

Tikus dianestesi menggunakan eter dan 
diotopsi untuk mendapatkan organ ginjal. Untuk pemeriksaan mikroskopik jaringan ginjal dibuat sediaan histopatologik di Pusat Diagnostik Patologi Anatomi Manado dan selanjutnya dilakukan perbandingan gambaran histopatologik ginjal tikus wistar kelompok kontrol dan perlakuan.

\section{HASIL PENELITIAN DAN BAHASAN}

Gambaran mikroskopik jaringan ginjal tikus wistar kontrol negatif terlihat normal (Gambar 1), sedangkan ginjal tikus wistar kontrol positif yang diberikan gentamisin menunjukkan adanya gambaran degenerasi hidropik, nekrosis dan fibrosis. Hal ini terjadi akibat gentamisin dosis toksik terakumulasi di ginjal sehingga menyebabkan sel epitel tubulus dan endotel kapiler mengalami cedera oksidatif dari pembentukan reactive oxygen species (ROS) yang berlebihan ${ }^{10}$ sehingga sel epitel tubuli rusak dan mengalami nekrosis tubulus akut (NTA).

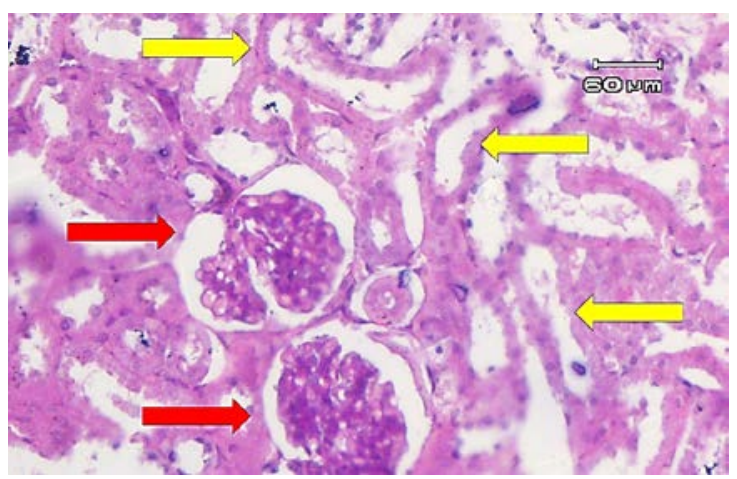

Gambar 1. Gambaran mikroskopik ginjal tikus wistar Kelompok I (kontrol negatif). Tampak glomerulus (panah merah) dan tubulus (panah kuning) yang normal.

Gambaran mikroskopik ginjal tikus Wistar yang diinduksi gentamisin selama 7 hari (Kelompok IIA) menunjukkan struktur glomerulus normal dengan sebagian besar sel-sel mengalami degenerasi hidropik dan sebagian kecil fokus nekrosis (Gambar 2). Gambaran mikroskopik ginjal tikus wistar yang diinduksi gentamisin 10 hari (Kelompok IIB) menunjukkan fokus luas nekrosis dengan membran basal tubulus yang masih utuh serta sebagian kecil area degenerasi hidropik (Gambar 3), selain itu tampak juga beberapa fokus yang sudah mengalami fibrosis (Gambar 4).

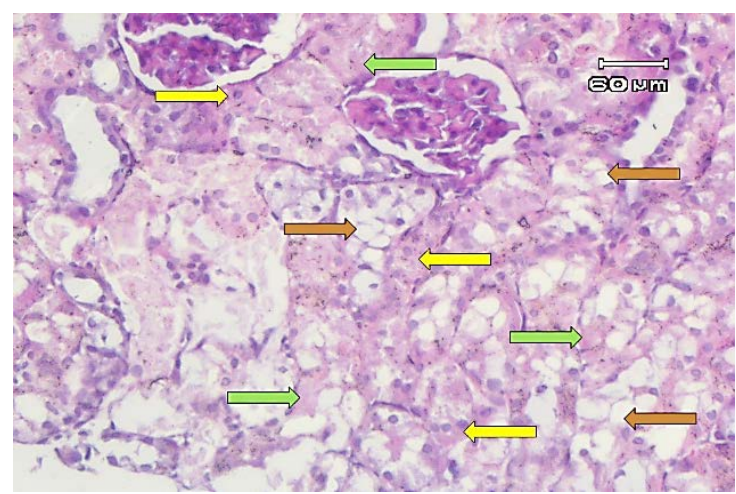

Gambar 2. Gambaran mikroskopik ginjal tikus wistar IIA (perlakuan injeksi gentamisin selama 7 hari). Tampak pembengkakan sel-sel epitel tubulus (panah kuning), sitoplasma bervakuol (panah coklat) dan inti sel menghilang (kariolisis) (panah hijau).

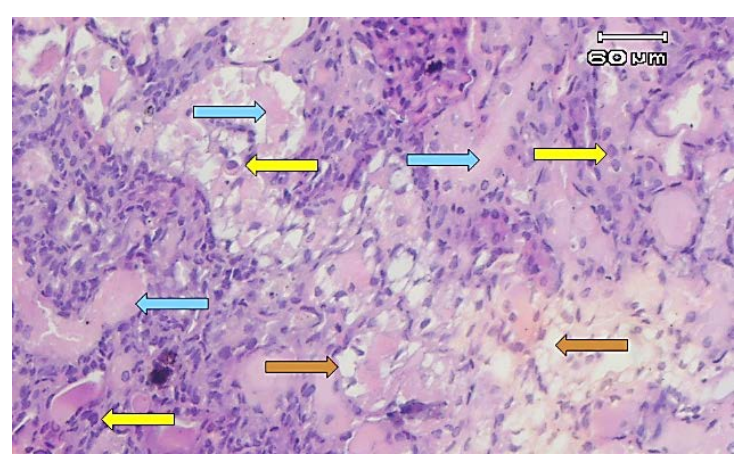

Gambar 3. Gambaran mikroskopik ginjal tikus wistar Kelompok IIB (perlakuan injeksi gentamisin selama 10 hari). Cast hialin tampak pada hampir seluruh lumen tubulus (panah biru). Sebagian inti sel tampak lebih basofilik (panah kuning) dan sitoplasma bervakuol (panah coklat).

Pembengkakan sel atau perubahan hidropik atau degenerasi vakuolar merupakan cedera awal yang masih reversibel. Perubahan sel ini muncul ketika sel tidak mampu mempertahankan homeostasis ionik dan cairan. $^{11}$ Pada penelitian ini degenerasi hidropik ditandai dengan sel-sel epitel tubulus yang membesar dan pucat serta vakuol jernih dalam sitoplasma sehingga menyebabkan lumen tubulus menjadi lebih sempit. 


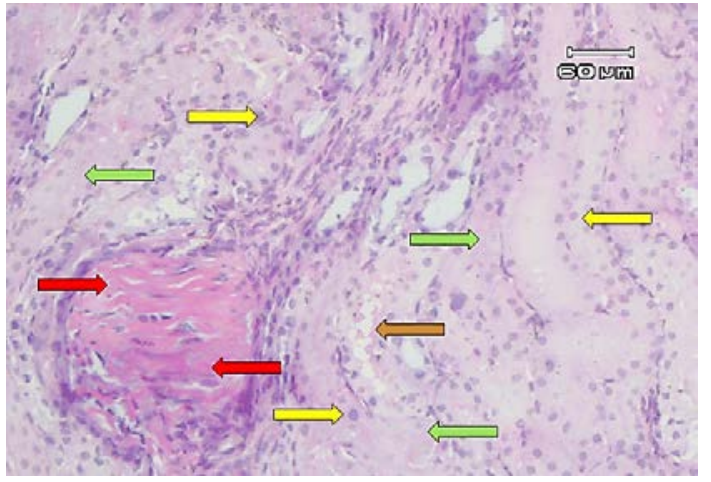

Gambar 4. Gambaran mikroskopik ginjal tikus wistar Kelompok IIB (perlakuan injeksi gentamisin selama 10 hari). Tampak area yang mengalami fibrosis (panah merah), sitoplasma bervakuol (panah coklat), inti sel yang lebih basofilik (panah kuning), dan inti yang hilang (kariolisis) (panah hijau).

Hasil penelitian yang didapatkan ini sesuai dengan hasil penelitian yang diperoleh oleh Sondakh (2012) ${ }^{4}$, disebutkan bahwa terjadi perubahan pada ginjal tikus wistar yang diberikan gentamisin selama 7 dan 10 hari yaitu adanya sel-sel tubulus yang mengalami degenerasi hidropik, nekrosis dan perlemakan ginjal di antara tubulus. $^{4}$

Cedera yang persisten atau berlebihan menyebabkan sel masuk ke kondisi jejas ireversibel. Keadaan ini disertai kerusakan luas pada semua membran, pembengkakan lisosom, dan vakuolisasi mitokondria, sehingga terjadi penurunan kapasitas untuk membentuk ATP. Akhirnya sel yang berada pada titik tidak dapat balik (point of no return) akan mati. Pada penelitian ini nekrosis ditandai dengan sitoplasma yang lebih eosinofilik, inti sel yang lebih basofilik maupun menghilang (kariolisis) dan adanya cast hialin (massa amorf merah muda) dalam lumen tubulus yang terbentuk akibat sel yang nekrosis., ${ }^{3,11,12}$ Selain itu, pada tubulus yang nekrotik tampak struktur tubulus masih ada membrana basalis yang masih utuh. Hal ini sesuai dengan teori kepustakaan yang menyebutkan NTA tipe toksik ditandai dengan membran basalis yang masih utuh. ${ }^{3,11}$

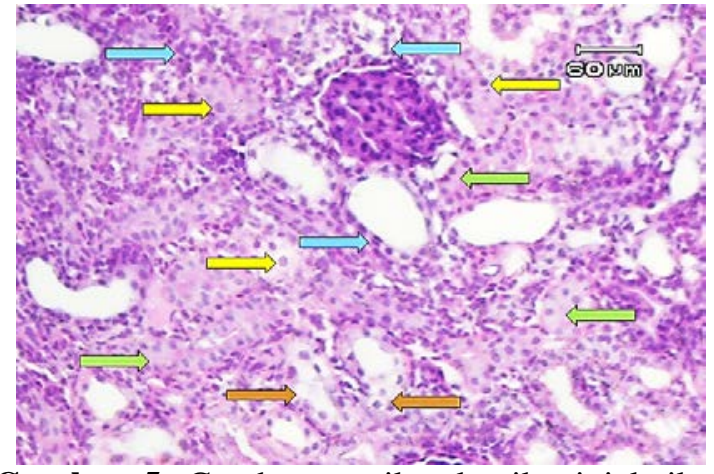

Gambar 5. Gambaran mikroskopik ginjal tikus wistar Kelompok IIIA (perlakuan injeksi gentamisin 7 hari dilanjutkan ekstrak ubijalar ungu 7 hari). Tampak jelas inti sel yang membesar (panah kuning) dan membelah (panah biru), sel yang membesar (panah hijau), serta vakuola jernih (panah coklat).

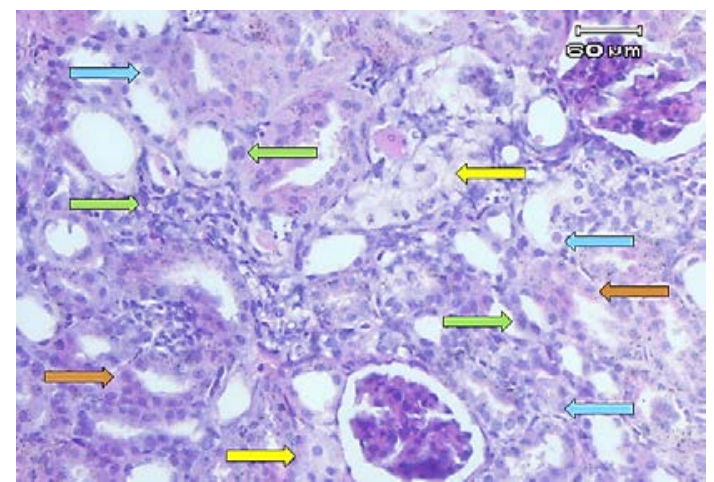

Gambar 6. Gambaran mikroskopik ginjal tikus wistar Kelompok IIIB (perlakuan injeksi gentamisin 10 hari dilanjutkan ekstrak ubijalar ungu 7 hari). Tampak inti sel yang membesar (panah biru) dan bersusun (panah hijau), sel yang membesar (panah coklat), serta fokus degenerasi hidropik (panah kuning).

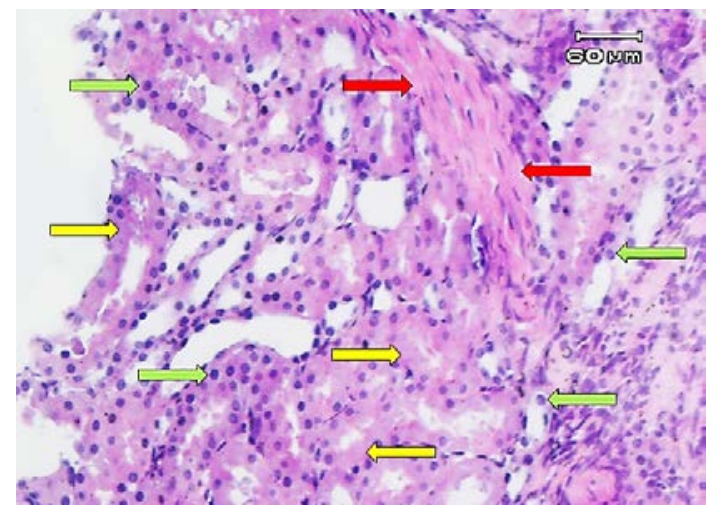

Gambar 7. Gambaran mikroskopik ginjal tikus wistar Kelompok IIIB (perlakuan injeksi gentamisin 10 hari dilanjutkan ekstrak ubijalar ungu 7 hari). Pada sediaan ini tampak satu fokus jaringan yang mengalami fibrosis (panah merah), sitoplasma sel bervakuol dan inti menghilang (panah kuning), serta sel berinti lebih basofilik (panah hijau). 
Pada gambaran mikroskopik ginjal tikus Wistar yang mendapatkan ekstrak ubi jalar ungu maupun pelet paska induksi gentamisin didapatkan regenerasi sel epitel tubulus ginjal. Hal ini sesuai dengan teori yang disebutkan bahwa pemulihan fungsi dapat terjadi dengan menghilangkan agen penyebab. ${ }^{1,2}$ Selain itu, regenerasi sel epitel tubulus terjadi karena sel epitel tubulus ginjal termasuk sel stabil, yaitu mampu membelah diri dengan cepat dalam hal merespons cedera, namun beristirahat dalam keadaan normal.,11 Pada pasien yang bertahan selama seminggu akan mulai tampak regenerasi epitel dalam bentuk lapisan epitel kuboid rendah serta aktivitas mitotik di sel epitel tubulus yang tersisa. ${ }^{11}$ Selanjutnya, setelah dua minggu banyak didapatkan tubulus proksimal yang dilapisi oleh sel epitel kuboidal. ${ }^{12}$ Regenerasi sel yang tampak pada penelitian ini ialah selsel yang berproliferasi (sel membesar dengan inti dua), sitoplasma tampak homogen merah muda dengan inti basofilik yang membesar dan lumen tubulus yang lebih lebar walaupun belum terbentuk sempurna.

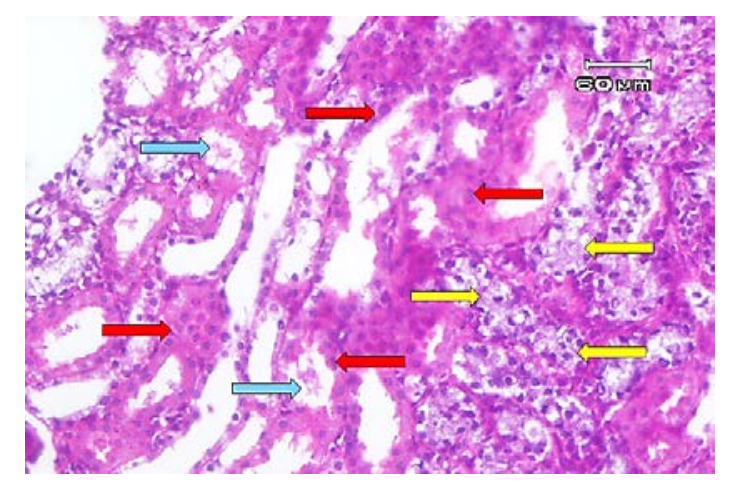

Gambar 8. Gambaran mikroskopik ginjal tikus wistar Kelompok IV (perlakuan injeksi gentamisin selama 7 hari dilanjutkan dengan pemberian pelet selama 7 hari). Sel-sel berinti dua (panah merah), fokus degenerasi hidropik (panah kuning), serta cast hialin (panah biru).

Gambaran mikroskopik ginjal tikus wistar yang diinduksi gentamisin selama 7 hari dilanjutkan dengan pemberian ekstrak ubijalar ungu selama 7 hari (Kelompok IIIA) menunjukkan fokus kecil degenerasi hidropik dengan sebagian luas struktur ginjal yang sudah mengalami regenerasi (Gambar 5). Gambaran mikroskopik ginjal tikus wistar yang diinduksi gentamisin 10 hari dan dilanjutkan pemberian ekstrak ubijalar ungu selama 7 hari menunjukkan fokus kecil nekrosis, degenerasi hidropik dan fibrosis di samping fokus-fokus yang sudah mengalami regenerasi (Gambar 6 dan Gambar 7). Berbeda dengan gambaran mikroskopik ginjal tikus wistar yang diinduksi gentamisin selama 7 hari dilanjutkan dengan pemberian pelet selama 7 hari (Kelompok IV) menunjukkan daerah yang sudah mengalami regenerasi diantara fokus-fokus yang masih mengalami degenerasi hidropik. Hal ini ditandai dengan lumen tubulus yang sudah melebar kembali walaupun masih tampak cast hialin didalamnya. (Gambar 8).

Pada penelitian ini, regenerasi sel ditemukan lebih banyak pada kelompok yang mendapatkan ekstrak ubijalar ungu dibandingkan dengan kelompok yang hanya mendapat pelet. Proses regenerasi sel yang terjadi pada penelitian ini diduga berkaitan dengan peran dari ekstrak ubijalar ungu. Ekstrak ubi jalar ungu yang mempunyai senyawa antosianin berfungsi sebagai antioksidan, ${ }^{7,13}$ sehingga mengurangi cedera sel yang terbentuk dengan menambah jumlah antioksidan eksogen dalam tubuh untuk mengimbangi antioksidan endogen. Hal ini sesuai dengan mekanisme terjadinya NTA tipe toksik yang salah satunya diakibatkan oleh pembentukan radikal bebas. ${ }^{5}$

Selain regenerasi, proses pemulihan jaringan yang kedua ialah fibrosis. Fibrosis terjadi akibat jejas jaringan berat atau menetap yang disertai kerusakan pada sel parenkim dan kerangka stroma yang menimbulkan suatu keadaan yang pemulihannya tidak dapat dilaksanakan melalui regenerasi parenkim saja. Dalam kondisi seperti ini, pemulihan terjadi melalui penggantian sel parenkim nonregeneratif oleh jaringan ikat. ${ }^{11}$ Pada penelitian ini didapatkan kelompok tikus yang mendapat gentamisin selama 10 hari, baik yang mendapat ekstrak ubi jalar ungu maupun pelet ditemukan fokus kecil 
jaringan fibrosis dalam interstisium ginjal.

\section{SIMPULAN}

Berdasarkan hasil penelitian ini didapatkan bahwa pemberian gentamisin dosis toksik 0,3 ml/ekor selama 7 dan 10 hari menunjukkan degenerasi hidropik dan nekrosis, selain itu gambaran fibrosis juga tampak pada kelompok yang menerima gentamisin selama 10 hari. Pemberian ekstrak ubijalar ungu 200 mg/ekor selama 7 hari pada tikus wistar yang telah diinduksi gentamisin $0,3 \mathrm{ml}$ menunjukkan regenerasi sel epitel tubulus secara luas serta fokus degenerasi hidropik dan nekrosis semakin berkurang sedangkan pada tikus perlakuan tanpa pemberian ekstrak ubijalar ungu menunjukkan regenerasi sel epitel tubulus ginjal namun masih terlihat banyak sel epitel tubulus ginjal yang mengalami degenerasi hidropik dan nekrosis.

Dari hasil penelitian dapat disimpulkan bahwa pemberian ekstrak ubi jalar ungu pada tikus wistar paska induksi gentamisin menunjukkan regenerasi sel epitel tubulus lebih luas dibandingkan yang tanpa pemberian ekstrak ubijalar ungu.

\section{SARAN}

1. Sebaiknya setelah autopsi pemeriksaan secara makroskopik juga dilakukan dengan menimbang kedua ginjal menggunakan timbangan analitik untuk mengetahui apakah pembesaran ginjal antar kelompok diikuti dengan perbedaan berat ginjal.

2. Pada penelitian berikutnya disarankan menambah jumlah dosis ekstrak ubijalar ungu yang digunakan.

\section{DAFTAR PUSTAKA}

1. Istiantoro YH, Gan VHS. Aminoglikosid. Dalam: Gunawan SG, Nafrialdi RS, Elysabeth, editors. Farmakologi dan Terapi (5th ed). Jakarta: Balai Penerbit FKUI, 2008; p.705-17.

2. Chambers HF. Aminoglycocides \& spectinomycin. In: Katzung BG, ed. Basic \& Clinical Pharmacology (11th ed). New York: McGraw-Hill Medical, 2009.

3. Alpers CE, Chang A. The Kidney. In:
Kumar V, Abbas AK, Aster JC, editors. Robbins and Cotran Pathologic basis of disease (9th ed). Philadelphia: Saunders, 2015; p. 897957.

4. Sondakh PLN. Gambaran Histopatologi Ginjal Tikus Wistar (Rattus norvegicus) yang Telah Diinduksi Gentamisin Terhadap Pemberian Jahe (Zingiber officinale) [Skripsi]. Manado: Fakultas Kedokteran Universitas Sam Ratulangi; 2012.

5. Lopez-Novoa JM, Yaremi Q, Vicente L, Morales AI, Lopez-Hernandez FJ. New Insights into the mechanism of aminoglycoside nephrotoxicity: an integrative point of view. Kidney International 2011;79:33-45.

6. Elango V, Vallabi DE. Effect of Ipomea obscura Linn in Nephrotoxic Induced in Experimental Rats. World Journal of Pharmaceutical Research. 2015;4:1641-51.

7. Ginting E, Utomo JS, Yulifianti R, Jusuf M. Potensi ubijalar ungu sebagai pangan fungsional [Internet]. Puslitbangtan. 2011;6:116-38 [cited 2015 Sep 16]. Available from: http://pangan.litbang.pertanian.go.id/f iles/09-erliana.pdf.

8. Husna NE, Novita M, Rohaya S. Kandungan Antosianin dan Aktivitas Antioksidan Ubi Jalar Ungu Segar dan Produk Olahannya. Agritech. 2013;33:296-302.

9. Pandir D, Kara O. Cisplatin-Induced Kidney Damage and Protective Effect of Bilberry (Vaccinum myrtillus L.): an experimental study. Tubitak. 2013;43:951-956.

10. Markum H. Gagal ginjal akut. In: Sudoyo AW, Setiyohadi B, Alwi I, K MS, Setiati S, penyunting. Buku Ajar Ilmu Penyakit Dalam. Jakarta: Pusat Penerbitan Departemen Ilmu Penyakit Dalam FKUI, 2006; p. 585-9.

11. Cotran RS, Rennke H, Kumar V. Buku Ajar Patologi (7th ed). Jakarta: EGC, 2007.

12. Cohen AH. Acute Tubular Necrosis. In: Fogo AB, editor. Fundamentals of Renal Pathology. New York: Springer, 2006; p. 153-157.

13. Wahyuni TS, Wargiono J. Morfologi dan Anatomi Tanaman. In: Ubi jalar: 
Jurnal e-Biomedik (eBm), Volume 4, Nomor 1, Januari-Juni 2016

Inovasi Teknologi dan Prospek

Pengembangan. Bogor: Pusat

Penelitian dan Pengembangan

Tanaman Pangan; 2011 [cited 2015
Okt 7]. Availale from:

http://balitkabi.litbang.pertanian.go.id /images/stories/uploads/publikasi/buk u/monograf/UJ-Bab-1-3.pdf. 